\title{
Peertechz
}

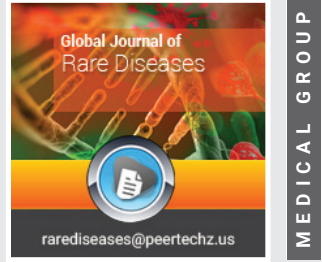

Mini Review

\section{Diabetes and COVID-19, potentialities of Morus alba L. (mulberry) and Stevia rebaudiana Bertoni (stevia).}

\section{Mini-review}

\section{Claudia Chávez Hernández ${ }^{1}$, Juan Abreu Payrol1,2*, Sirley González Laime ${ }^{1}$, Ariel Martínez García ${ }^{1,3}$, Lázaro Michel, Morera Legarreta ${ }^{1}$ and Marisol González Pérez ${ }^{1}$}

${ }^{1}$ ECTI Sierra Maestra, Complejo Barlovento Ave 5ta and 246, Santa Fé, Playa, Havana, Cuba

${ }^{2}$ Latin American School of Medicine, Carretera Panamericana, km 3 1⁄2, Santa Fé, Playa, Havana, Cuba ${ }^{3}$ Institute of Materials Science and Technology, University of Havana, Zapata y G, Vedado, Havana, Cuba
Received: 21 July, 2021

Accepted: 09 August, 2021

Published: 10 August, 2021

*Corresponding author: Juan Abreu Payrol, ECTI Sierra Maestra, Complejo Barlovento Ave 5ta and 246, Santa Fé, Playa, Havana, Cuba,

E-mail: jabreu@bionaturasm.cu

Keywords: Morus alba; Mulberry; Stevia rebaudiana; Stevia; COVID-19; Diabetes; Flavonoids

https://www.peertechzpublications.com

\section{Check for updates}

\begin{abstract}
Diabetes mellitus is one of the main comorbidities associated with mortality and severe disease in infections with SARS-CoV-2. Extracts from the leaves of Morus alba and Stevia rebaudiana are used in traditional medicine to control diabetes. A brief review is made of the potential of these extracts to improve the conditions associated with COVID-19, not only through the control of diabetes but also for the presence of chemical compounds, particularly flavonoids, which have shown antiviral activity in pharmacological and in silico studies.
\end{abstract}

\section{Introduction}

At the beginning of 2020, the pandemic caused by the SARS-CoV-2 virus broke out. Although the pathophysiological mechanisms of its action are not yet well defined, it is observed that most of the cases that result in severity or death correspond to patients with associated pathologies, such as cardiovascular diseases, diabetes mellitus, chronic lung and kidney disease, hypertension and cancer, so special attention should be paid to people with underlying conditions such as those mentioned $[1,2]$.

Diabetes is one of the leading causes of death in the world and is associated with several macros and microvascular complications, which ultimately affect the overall survival of the patient [3]. Uncontrolled blood glucose is recognized as a significant predictor of severity and death in patients infected with different viruses, including pandemic influenza A 2009 (H1N1) [4], SARS-CoV [5] y MERS-CoV [6]. In the current SARS-CoV-2 pandemic, some studies did not find a clear association between diabetes and severe disease [7]. However, other reports from China [1,2] and Italy [8] showed that older patients with chronic diseases, including diabetes, had an increased risk of severe COVID-19 and mortality.

\section{Mulberry in COVID-19}

Mulberry (Morus alba) is a plant of Asian origin whose chemical composition there are flavonoids with known biological activity. It is recognized as an important functional food due to the presence of bioactive compounds, including flavonoids such as anthocyanins, rutin, quercetin, and 
isoquercitrin. At least 44 flavonoids have been isolated from 91 species and varieties of mulberry, as glycosidic and acylated derivatives, in relatively large quantities, standing out for their antioxidant potential [9]. In China, the leaves are consumed as an infusion as a healthy drink, and they have also been included in food products, supplied as healthy foods to regulate blood sugar levels, useful for controlling type 2 diabetes mellitus $[10]$.

Multiple studies indicate that mulberry leaf extract has an important postprandial hypoglycemic effect, through the inhibition of $\alpha$-glucosidase and glucose transport [11]. The leaves of $M$. alba contain 1-deoxynojirimycin (DNJ, a potent inhibitor of $\alpha$-glycosidase) and other iminosugars, which also have the ability to lower blood glucose levels, such as 2-O- $\alpha$ D-galactopyranosyl- DNJ (GAL-DNJ), D-phagemine (FAG) and 4-O- $\beta$-D-glucopyranosyl-phagemine (Glu-FAG). The same occurs in sericulture products, including the silkworm, Bombyx mori [12]. These compounds are beneficial in suppressing abnormally high blood glucose levels, thus preventing diabetes mellitus [13].

A recent study on Chinese medicinal plants with the potential to directly inhibit the 2019 novel coronavirus reveals the validity of this research approach. In this in silico study, the potential of plants and compounds they contain to act on three attractive targets of SARS-CoV-2, Papain-Like Protease (PLpro) [processes the viral polypeptide into functional proteins, and is a desubiquitinant enzyme that dampens the host's antiviral response by sequestering the Ubiquitin System (Ub)], type 3C protease (3CLpro) (cysteine protease essential for the viral life cycle) and spike protein (uses angiotensin-converting enzyme 2 as a receptor for virus entry into cells). As a result 13 natural compounds and 26 medicinal plants were selected to treat respiratory viral infection, as they contain direct antiCOVID-19 compounds [7]. Among the selected compounds are the flavonoids kaempferol and quercetin, present in mulberry leaves (potentially inhibiting PLpro and 3CLpro proteases) and among selected plants, mulberry leaves (Mori folium), to be used during the entire course of the disease.

Mulberry is the main ingredient in the formulas Sang Ju Yin (Mori folium) and Xie Bai San (Mori cortex). Taking these forecasts into account, Kwong, et al. [14] selected the 6 most promising plants and looked for traditional Chinese medicine formulations where they were part to evaluate them in their clinical application. Among COVID-19 pneumonia cases, 41.8 $\%$ developed acute respiratory distress syndrome (ARDS); therefore, interrupting the progression from pneumonia to ARDS is key to lowering the death rate from COVID-19 [15]. They recommended starting with Sang Ju Yin and Xie Bai San as soon as possible, especially at the beginning of dyspnea and before ARDS, considered a critical condition, that is, for mild/ moderate cases (not for severe condition), aiming to prevent patients from progressing to severe cases. Sang Ju Yin and Xie Bai San could play a protective role before the development of ARDS, although results of clinical trials are needed to confirm that presumption [14].

\section{Stevia in COVID - 19}

The consumption of foods low in sugar has become a fastgrowing trend worldwide. In this sense, Stevia rebaudiana is positioned as a source of high-potency sweetener, which produces a sweet taste without adding caloric value. More than 40,000 clinical studies have been conducted in Japan showing that steviol glycosides are safe when used as sweeteners [16]. Non-nutritive sweeteners are sugar substitutes that have zero calories and do not raise blood glucose levels. They may be the preferred option for reducing carbohydrate and calorie intake in people with diabetes [17], being the indirect way in which steviol glycosides reduce postprandial blood glucose concentrations: displacing sucrose or other carbohydrates ( [18]. However, some preclinical and clinical studies for steviol glycosides suggest a possible independent effect of reducing postprandial blood glucose concentrations, increasing insulin secretion, and improving insulin sensitivity in subjects with diabetes, with some mechanistic evidence for these effects, which appear to involve insulin secretion, signalling, and release; positive regulation of key genes and improved glucose uptake. Additional clinical studies are needed to clarify and confirm these findings [19].

For stevia extracts also are reported benefits as antioxidants and blood pressure reducers. In addition to steviol glycosides, this plant contains several phytochemicals, including phenols and flavonoids [20]. The aforementioned properties allow the use of the aqueous and alcoholic extracts of this plant and the steviol glycosides in herbal medicines for diabetic patients as a pharmacological alternative, which makes them potentially valuable in order to reduce the risk of severity and death from COVID - 19 [16].

Crude extracts of $S$. rebaudiana leaves showed a very potent radical scavenging activity towards reactive oxygen species and reactive nitrogen species. This could explain why raw leaf extracts were more efficient in the care of type 2 diabetes, as shown by Ferreira, et al. [21].

So far there are few reports linking the use of stevia with beneficial effects to counteract the harmful effects of COVID - 19. COVID-19 is related to an imbalance of radicals and antioxidants [22], it could be successful to evaluate the effects of steviol glycosides and raw stevia extracts, which have much better radical scavenging activity than vitamin $\mathrm{C}$ $[23,24]$. The presence of steviol glucuronide in the blood has been reported after consuming stevia or steviol glycosides, a metabolite capable of capturing radicals in different organs of the human body, also taking into account that its level in the blood is sufficiently high $( \pm 5 \mu \mathrm{M}$ to $20 \mu \mathrm{M})$ and can be increased by doubling the intake. The raw extract of stevia leaf could be even better since the antioxidant activity of the leaf extract cannot be totally related to the steviol glycosides, some different compounds such as phenols and flavonoids present in the crude extract are effective antioxidants [22] .

Flavonoids are important chemical components in the leaves of $M$. alba and S. rebaudiana and are therefore associated with the activity of these traditional remedies. These compounds have

Citation: Hernández CC, Payrol JA, Laime SG, García AM, Miche L, et al. (2021) Diabetes and CoVID-19, potentialities of Morus alba L. (mulberry) and Stevia rebaudiana Bertoni (stevia). Mini-review. Glob J Rare Dis 6(1): 006-009. DOI: https://dx.doi.org/10.17352/2640-7876.000031 
been shown to inhibit viral pathogenesis by targeting essential stages of the viral life cycle [25]. A very comprehensive review of the benefits of flavonoids in COVID-19 disease, based on previously reported effects of flavonoids on five RNA viruses with similar clinical manifestations and/or pharmacological treatments, including influenza, Human Immunodeficiency Virus (HIV), Severe Acute Respiratory Syndrome (SARS), Middle East respiratory syndrome (MERS) and Ebola, has been considered as a basis to briefly summarize the possible mechanisms involved in the potential activity of the flavonoids present in the leaves of these plants, that can turn them into remedies to alleviate the consequences of infection with SARS - CoV - 2, as in vitro studies suggests [26,27].

\section{FLAVONOIDS ANTIVIRAL MECHANISMS}

\section{DIRECT}

\section{INDIRECT}

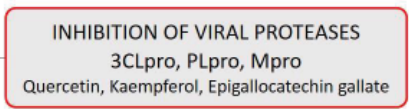

INHIBITION OF VIRAL RNA POLYMERASE AND VIRAL MRNA

Quercetin-7-glucoside, Quercetin, Luteolin

\section{VIRAL ENTRY, REPLICATION, INFECTIVITY} Quercetin and its glucosides, isoquercetin isorhamnetin
EFFECTS ON INTERFERONS (IFNs) Isoquercetin

$\begin{gathered}\text { EFFECT ON PRO-INFLAMMATORY } \\ \text { CYTOKINES } \\ \text { Quercetin-rhamnopyranose, Gallocatechin-7- } \\ \text { gallate }\end{gathered}$
EFFECT ON SUB-CELLULAR
INFLAMMATORY PATHWAYS
Isorhamnetin, 8-Prenylkaempferol

Inhibition of viral proteases is the most frequently reported direct antiviral mechanism of flavonoids. On the other hand, modulation of host inflammatory responses to viral infections appear to be the most important mechanism by which complications of viral infection are managed.

According to current literature, theaflavins, quercetin, luteolin, myricetin, kaempferol, catechins, hesperidin, and baicalin were the most promising flavonoids against the aforementioned viruses.

Flavonoids are promising compounds for controlling SARS-CoV-2 infection. Future experimental mechanical and clinical studies are needed to further clarify the role of these compounds in the primary and secondary prevention of SARSCoV-2 infection [25].

Quercetin, luteolin, kaempferol and their derivatives exist as main components in the leaves of both plants; together with other components of a phenolic nature $(10,28)$; isoquercetin, isorhamnetin and their derivatives, as well as epigallocatechin gallate gallocatechin-7-gallate, have also been reported in mulberry leaves [10].

\section{Conclusions}

Mulberry and stevia are plants that contain components that are used effectively for the treatment of one of the most dangerous comorbidities in COVID-19, diabetes. In addition, they contain compounds that can reduce infection with SARSCoV-2 and potentially prevent the evolution towards the severity or death of patients with the disease, flavonoids are outstanding among these.

\section{References}

1. Yang J, Zheng Y, Gou X, Pu K, Chen Z, et al. (2020) Prevalence of comorbidities and its effects in patients infected with SARS-CoV-2: a systematic review and meta-analysis. Int J Infect Dis 94: 91-95. Link: https://bit.ly/2Vxv413

2. Zhou F, Yu T, Du R, Fan G, Liu Y, et al. (2020) Clinical course and risk factors for mortality of adult inpatients with COVID-19 in Wuhan, China: a retrospective cohort study. Lancet 395: 1054-1062. Link: https://bit.ly/2VFHDY6

3. Williams R, Karuranga S, Malanda B, Saeedi P, Basit A, et al. (2020) Global and regional estimates and projections of diabetes-related health expenditure: Results from the International Diabetes Federation Diabetes Atlas, 9th edition. Diabetes Res Clin Pract 162: 108072. Link: https://bit.ly/3AvWQtk

4. K, Horvat N, Guerreiro NFC, de Castro I, de Giassi KS (2019) Spectrum of clinical and radiographic findings in patients with diagnosis of $\mathrm{H} 1 \mathrm{~N} 1$ and correlation with clinical severity. BMC Infect Dis 19: 964. Link: https://bit.ly/37AxIFm

5. Yang JK, Feng Y, Yuan MY, Yuan SY, Fu HJ, et al. (2006) Plasma glucose levels and diabetes are independent predictors for mortality and morbidity in patients with SARS. Diabet Med 23: 623-628. Link: https://bit.ly/3AsPHu6

6. Banik GR, Alqahtani AS, Booy R, Rashid H (2016) Risk factors for severity and mortality in patients with MERS-CoV: Analysis of publicly available data from Saudi Arabia. Virol Sin 31: 81-84. Link: https://bit.ly/3IO0lax

7. Zhang DH, Wu KL, Zhang X, Deng SQ, Peng B (2020) In silico screening of Chinese herbal medicines with the potential to directly inhibit 2019 novel coronavirus. J Integr Med 18: 152-158. Link: https://bit.ly/2U4wKhE

8. Onder G, Rezza G, Brusaferro S (2020) Case-Fatality Rate and Characteristics of Patients Dying in Relation to COVID-19 in Italy. JAMA 323: 1775-1776. Link: Link: https://bit.ly/3IMYVNs

9. Li D, Chen G, Ma B, Zhong C, He N (2020) Metabolic Profiling and Transcriptome Analysis of Mulberry Leaves Provide Insights into Flavonoid Biosynthesis. J Agric Food Chem 68: 1494-1504. Link: https://bit.ly/3ITXm05

10. Chan EWC, Lye PY, Wong SK (2016) Phytochemistry, pharmacology and clinical trials of Morus alba. Chin J Nat Med 14: 17-30. Link: https://bit.ly/3ixSjR6

11. Chen F, Nakashima N, Kimura I, Kimura M (1995) Hypoglycemic activity and mechanisms of extracts from mulberry leaves (folium mori) and cortex mori radicis in streptozotocin-induced diabetic mice. Yakugaku Zasshi 115: 476482. Link: https://bit.ly/2VyT97K

12. Nakagawa K, Ogawa K, Higuchi O, Kimura T, Miyazawa T, et al. (2010) Determination of iminosugars in mulberry leaves and silkworms using hydrophilic interaction chromatography-tandem mass spectrometry. Anal Biochem 404: 217-222. Link: https://bit.ly/37xWxSo

13. Kimura T, Nakagawa K, Kubota H, Kojima Y, Goto Y, et al. (2007) Food-grade mulberry powder enriched with 1-deoxynojirimycin suppresses the elevation of postprandial blood glucose in humans. J Agric Food Chem 55: 5869-5874. Link: https://bit.ly/3AuEfhy

14. Kwong $P$, Lin $Y$, Chen C (2020) A strategy of traditional Chinese medicine against COVID-19: linking current basic research and ancient medicine texts. Int J Complement Alt Med 13. Link: https://bit.ly/3fOtzSN

15. Wu C, Chen X, Cai Y, Xia J, Zhou X, et al. (2020) Risk Factors Associated With Acute Respiratory Distress Syndrome and Death in Patients With Coronavirus Disease 2019 Pneumonia in Wuhan, China. JAMA Intern Med 180: 934-943. Link: https://bit.ly/3IL3JmE

16. Gupta E, Purwar S, Sundaram S, Rai G (2013) Nutritional and therapeutic values of Stevia rebaudiana: A review. Journal of Medicinal Plants Research 7 3343-3353. Link: https://bit.ly/3jFaRyd 
17. Shin D, Lee J, Kang M, Kim T, Jeong S, et al. (2016) Glycemic Effects of Rebaudioside A and Erythritol in People with Glucose Intolerance. Diabetes Metab J 40: 283-289. Link: https://bit.ly/3IPYd26

18. Gardner C, Wylie-Rosett J, Gidding SS, Steffen LM, Johnson RK, et al. (2012) Nonnutritive sweeteners: current use and health perspectives: a scientific statement from the American Heart Association and the American Diabetes Association. Circulation 126: 509-519. Link: https://bit.ly/3ClsPsz

19. Samuel P, Ayoob KT, Magnuson BA, Wölwer-Rieck U, Jeppesen PB, et al. (2018) Stevia Leaf to Stevia Sweetener: Exploring Its Science, Benefits, and Future Potential. J Nutr 148: 1186S-1205S. Link: https://bit.ly/3CBTjvq

20. Carrera-Lanestosa A, Moguel-Ordonez Y, Segura-Campos M (2017) Stevia rebaudiana Bertoni: A Natural Alternative for Treating Diseases Associated with Metabolic Syndrome. J Med Food 20: 933-943. Link: https://bit.ly/3IOsrT9

21. Bega Ferreira E, Rocha Neves FA, Duarte da Costa MA, Alves do Prado W, de Araujo Funari Ferri L, et al. (2006) Comparative Effects of Stevia rebaudiana Leaves and Stevioside on Glycaemia and Hepatic Gluconeogenesis. Planta Med 72: 691 - 696. Link: https://bit.ly/3xzyddD
22. Geuns Jan M (2020) Can Stevia Reduce Inflammation in COVID-19 Disease Arch Food Sci Nutr Res 1: 1001. Link: https://bit.ly/3Akcb0e

23. Geuns J, Hajihashemi S (2014) Stevia and steviol glycosides: Pharmacological effects and radical scavenging activity. In W. Wu (Ed.), Leaf Sweeteners and health. New York: (c) 2015 Nova Science Publishers, Inc 123 - 147.

24. Hajihashemi S, Geuns JMC (2013) Free radical scavenging activity of stevio glycosides, steviol glucuronide, hydroxytyrosol, metformin, aspirin and leaf extract of Stevia rebaudiana. Free Radicals and Antioxidants 3: S34-S41. Link: https://bit.ly/3jCTQ7X

25. Sadati SM, Gheibi N, Ranjbar S, Hashemzadeh MS (2019) Docking study of flavonoid derivatives as potent inhibitors of influenza H1N1 virus neuraminidase. Biomed Rep 10: 33-38. Link: https://bit.ly/3CBKMZo

26. Khazeei Tabari MA, Iranpanah A, Bahramsoltani R, Rahimi R (2021) Flavonoids as Promising Antiviral Agents against SARS-CoV-2 Infection: A Mechanistic Review. Molecules 26: 3900. Link: https://bit.ly/3jlJFhY

27. Zhang JJ, Dong X, Cao YY, Yuan YD, Yang YB, et al. (2020) Clinica characteristics of 140 patients infected with SARS-CoV-2 in Wuhan, China. Allergy 75: 1730-1741. Link: https://bit.ly/3s5q53d
Discover a bigger Impact and Visibility of your article publication with Peertechz Publications

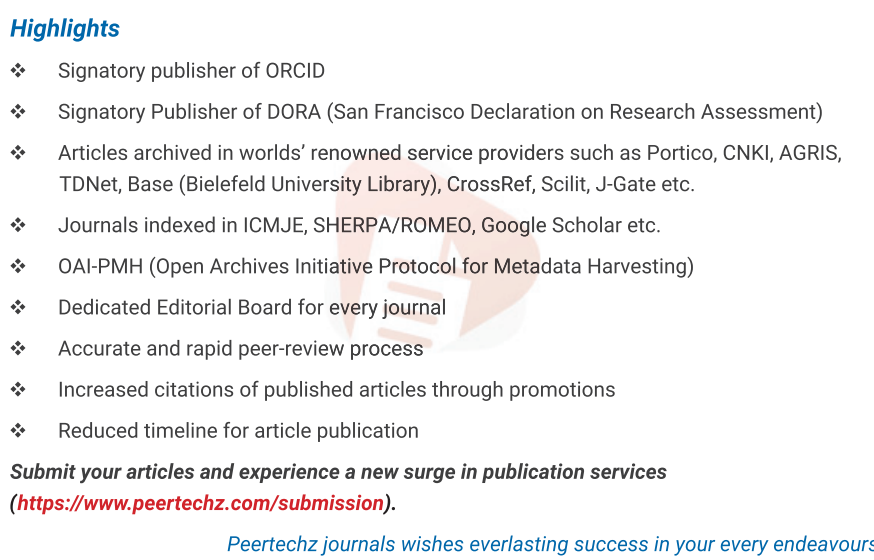

Copyright: @ 2021 Hernández CC, et al. This is an open-access article distributed under the terms of the Creative Commons Attribution License, which permits unrestricted use, distribution, and reproduction in any medium, provided the original author and source are credited.

Citation: Hernández CC, Payrol JA, Laime SG, García AM, Miche L, et al. (2021) Diabetes and CoVID-19, potentialities of Morus alba L. (mulberry) and Stevia rebaudiana Bertoni (stevia). Mini-review. Glob J Rare Dis 6(1): 006-009. DOI: https://dx.doi.org/10.17352/2640-7876.000031 